\title{
Time course of lung function changes in atypical pneumonia
}

\author{
L N BENUSIGLIO, H STALDER, AND A F JUNOD
}

From the Department of Medicine, Hôpital Cantonal Universitaire, Geneva, Switzerland

ABSTRACT We measured pulmonary function in each of 21 patients suffering from "atypical non-bacterial pneumonia during the acute illness and during convalescence (two to 18 months) to study the course and the nature of functional impairment at different stages of the disease. In sox patients, no aetiological agent was found. An aetiological agent was identified in 15 of the patient?: Mycoplasma pneumoniae (seven patients), influenza A (three patients), parainfluenza 3 (one patient), varicella (two patients), $\mathrm{Q}$ fever (one patient), coxsackie B3 (one patient). At the time of admission we observed a restrictive pattern in $52 \%$, an obstructive pattern (decreased $\mathrm{FEV}_{\mathbf{1}} / \mathrm{FVC}^{\mathrm{F}} \mathrm{ratio}$ ) $52 \%$, abnormalities in distribution of ventilation (abnormal slope of phase 3 ) in $63 \%$, and abnormalities in gas exchange (increased $\mathrm{AaDO}_{2}$ ) in $75 \%$ of the patients. The frequency abnormalities in these pulmonary function tests decreased dramatically after two to four weeks and nearly disappeared in most patients during convalescence. The only major residual abnormality woss a decreased $\mathrm{FEV}_{1} / \mathrm{FVC}$ ratio in five subjects, four of whom were smokers. However, when MME垔 and $\dot{V}_{75}$ were measured at this stage, their average value for all the groups of patients with the exclusion of the Mycoplasma pneumoniae group, was markedly reduced. These data suggest that small airways involvement can be demonstrated during the convalescence of patients recovering from various types of atypical pneumonia other than those caused by Mycoplasma pneumonia?

The development of tests thought to detect obstruction in small airways has led to their use to siudy the amount and duration of the functional impairment in the lung during uncomplicated viral infections. Thus, frequency dependence of both compliance and total resistance and decreased maximal airflows at low lung volume were observed in subjects suffering from viral upper airway infections or given live attenuated influenza vaccine, ${ }^{1-5}$ whereas abnormalities in more conventional tests were also detected in patients with uncomplicaied influenza or common cold. ${ }^{6-8}$ Other authors have demonstrated abnormalities during influenza ${ }^{9}$ and rhinovirus ${ }^{10}$ infections by measuring maximal airflows in patients breathing ambient air and then a $80 \%$ helium-20\% oxygen mixture. On the other hand, Zeck and co-workers ${ }^{11}$ analysed the single breath oxygen manoeuvre and were unable to find abnormalities in the slope of phase 3 in subjects who had received live attenuated influenza vaccine. Finally, increased bronchial

Address for reprint requests: Dr Alain F Junod, Respiratory Division, Department of Medicine, Hôpital Cantonal Universitaire, CH 1211 Geneva 4, Switzerland reactivity was found in patients suffering fro respiratory syncytial virus infection. ${ }^{12}$ The pros longed duration of these functional abnormalitie was stressed by several authors. ${ }^{1} 2$ 4-6812

In contrast, there are very few reports dealin with the effects of non-bacterial or "atypical pneumonia on respiratory function. Apart frop the exhaustive work by Berven ${ }^{13}$ on cardiopu monary function in the post-infec:icus phase $g$ atypical pneumonia, only a few studies have assessed lung function in this clinical con dition. 14-19 Therefore we studied prospectively patients admitted to hospital with the diagnosis of atypical pneumonia, to characterise the respiras tory functional disturbance during the time of acute illness, in the immediate recovery perio and from two to 18 months later. This study was meant to answer the following questions. Arc t!m functional alterations specifically related to the nature of the aetiological agent? Is the prognos \$ related to the initial lung function impairment $\frac{\text { Pे }}{\$}$ And, finally, is there evidence in patients with non-bacterial pneumonia of small airways disease the main dysfunotion in uncomplicated vira illness, and, if so, at which stage? 


\section{Methods}

During a nine-month period, 33 patients were admitted to the Hospital Cantonal in Geneva with an initial diagnosis of atypical pneumonia. Twenty-one of these patients were included in our study because they satisfied the following criteria: history of headache, sore throat, myalgia, rhinitis, and fever, in general preceding symptoms of lung involvement (dry cough, pleuritic chest pain); normal breath sounds by physical examination; diffuse lung infiltrates, sometimes with a ground glass-like appearance, seen on the chest radiograph; negative bacterial sputum and blood cultures. Of the 21 patients studied, 12 were smokers (all more than 10 cigarettes per day). The other patients had never smoked.

\section{VIROLOGICAL STUDIES}

We performed bedside nasopharyngeal washes with ice-cold phosphate buffered saline ${ }^{20}$ immediately after admission. The samples were taken without delay to the virus laboratory and a $0.2 \mathrm{ml}$ aliquot of the specimen was inoculated into each of two tubes containing primary human embryonic kidney cells (HEK) and human fibroblast cell strain (FS-9). The tubes were placed on a roller and incubated at $36^{\circ} \mathrm{C}$. Eagle's medium complemented with $2 \%$ fetal calf serum (FCS) (for HEK) and Dulbecco's medium with $2 \%$ FCS (for FS-9) were used for maintenance and changed at least once a week. The tubes were watched at least twice weekly for cytopathic effect. After four weeks, they were challenged with Echovirus 11. Haemadsorption with fresh guinea pig red blood cells was performed at least twice. Identification of viruses was performed using classical methods. ${ }^{21}$

\section{SEROLOGICAL STUDIES}

Samples of sera were taken from each patient on admission, at two to three weeks, and at two to 18 months thereafter for complement fixation tests $^{22}$ for the following antigens: Mycoplasma pneumoniae, adenovirus, influenza $\mathbf{A}$ and $\mathbf{B}$, ornithosis, Q fever, respiratory syncytial virus, adenovirus, and mumps (kindly performed by $\mathrm{Dr}$ MF Paccaud, Institut d'Hygiène. Geneva, Switzerland), Legionella and parainfluenza 1, 2, and 3 (kindly performed by the courtesy of $\mathrm{Dr}$ W Dowdle, Centre for Disease Control, Atlanta, Georgia). A fourfold or greater titre rise was considered to be diagnostic.

\section{LUNG FUNCTION TESTS}

We performed lung function tests on admission (acute stage or first series), two to three weeks (post-infectious stage or second series), and two to 18 months (convalescent stage or third series) thereafter. Total lung volumes and specific conductance were measured in a constant volume body plethysmograph. ${ }^{23}{ }^{24}$ We used a Godart bell spinometer to measure $\mathrm{FEV}_{1}, \mathrm{FVC}$, and MMEF. Closing volume and the slope of the alveolar plateau (phase 3) were measured during the single breath- $\mathrm{O}_{2}$-manoeuvre. ${ }^{25}$ We measured maximal flow-volume ( $\dot{\mathrm{V}}-\mathrm{V})$ curves using a wedge spirometer, recorded the signals on an $\mathrm{X}-\mathrm{Y}$ storage oscilloscope and photographed the screen to obtain a permanent record. We expressed maximal airflows at various lung volumes as the ratio of maximal flow/forced vital capacity ( $\dot{\mathrm{V}} \max / \mathrm{FVC}$ ). Knudson and co-workers ${ }^{26}$ have shown that the value of this ratio is essentially age-independent. Gas exchange studies were made in the sitting position and the alveolararterial gradient for $\mathrm{O}_{2}\left(\mathrm{AaDO}_{2}\right)$ calculated from the ideal alveolar air equation. Predicted values for lung volumes were taken from Goldman and Becklake, ${ }^{27}$ for the ratio $\mathrm{FEV}_{1} / \mathrm{FVC}$ from Berglund et $a{ }^{28}$ for MMEF from Morris et $a l,{ }^{29}$ for the ratio $\dot{V}_{75} / F V C$ from Knudson $e t a l,{ }^{2}$ for the slope of phase 3 during the single breath $\mathrm{O}_{2}$ manoeuvre from Buist and Ross. ${ }^{25}$ The use of pulmonary function equipment, similar or identical to ours, by these authors was the basis for the selection of these predicted values.

\section{Results}

Table 1 gives the distribution of the various types

Table 1 Causal agents and age, sex, and smoking habits of patients studied

\begin{tabular}{|c|c|c|c|c|}
\hline Aetiology & $\begin{array}{l}\text { Patient } \\
\text { number }\end{array}$ & $\begin{array}{l}\text { Age } \\
\text { (yr) }\end{array}$ & Sex & Smoker \\
\hline \multirow{7}{*}{$\begin{array}{l}\text { Mycoplasma } \\
\text { pneumoniae }\end{array}$} & 1 & 42 & $\mathbf{M}$ & - \\
\hline & 2 & 22 & $\mathbf{M}$ & - \\
\hline & 3 & 21 & $\mathbf{M}$ & + \\
\hline & 4 & 37 & $\mathbf{F}$ & + \\
\hline & 5 & 48 & $\mathbf{M}$ & - \\
\hline & 6 & 30 & $\mathbf{M}$ & - \\
\hline & 7 & 34 & $\mathbf{F}$ & - \\
\hline \multirow[t]{3}{*}{ Influenza $\mathbf{A}$} & 8 & 48 & $\mathbf{M}$ & + \\
\hline & 9 & 28 & $\mathbf{F}$ & - \\
\hline & 10 & 52 & $\mathbf{F}$ & - \\
\hline \multirow[t]{2}{*}{ Varicella } & 11 & 32 & $\mathbf{F}$ & + \\
\hline & 12 & 32 & $\mathbf{F}$ & + \\
\hline Coxsackie B & 13 & 34 & $\mathbf{F}$ & + \\
\hline$Q$ fever & 14 & 29 & $\mathbf{M}$ & + \\
\hline Parainfluenza A & 15 & 35 & $\mathbf{M}$ & - \\
\hline \multirow{6}{*}{ Unknown } & 16 & 67 & $\mathbf{M}$ & + \\
\hline & 17 & 43 & $\mathbf{M}$ & + \\
\hline & 18 & 30 & $\mathbf{M}$ & + \\
\hline & 19 & 32 & $\mathbf{M}$ & + \\
\hline & 20 & 23 & $\mathbf{F}$ & + \\
\hline & 21 & 50 & $\mathbf{F}$ & - \\
\hline
\end{tabular}




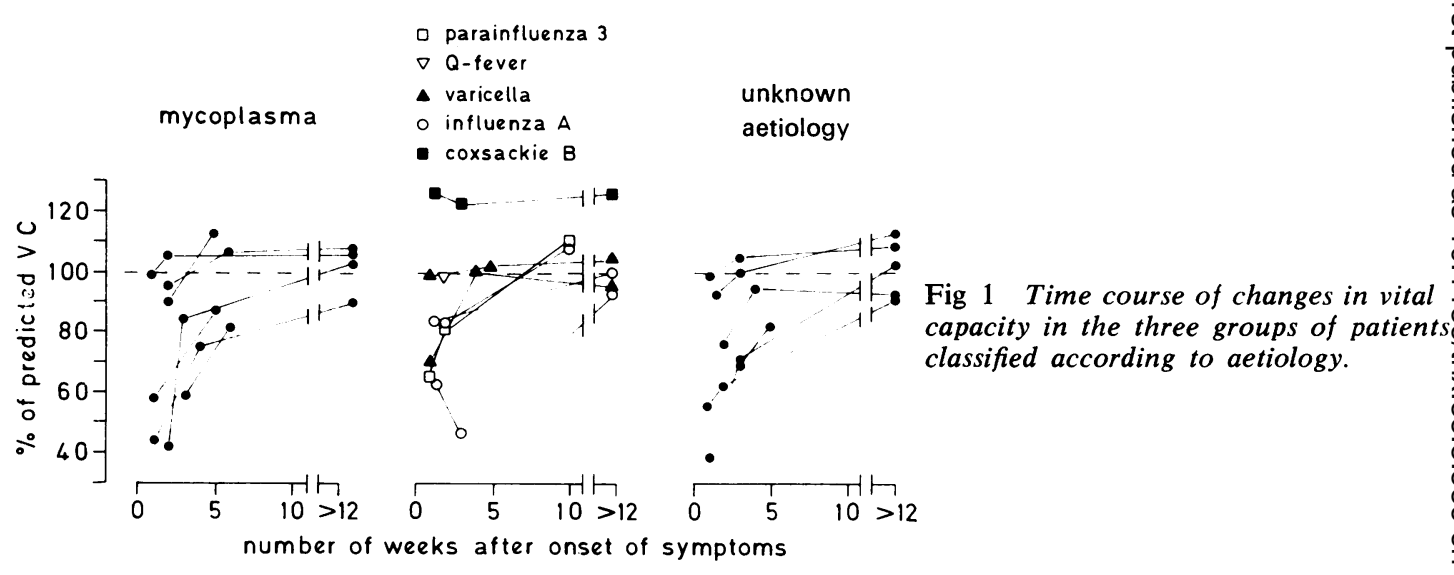

of causal agents, and the age, sex, and smoking habits of each patient. An aetiological agent could not be found in six patients $(29 \%)$.

In general, VC was decreased during the acute stage and returned to normal values $(>80 \%$ predicted) during the next five weeks (fig 1). We found that changes in VC were representative of the changes in TLC in all but three patients. A decrease in VC down to $80 \%$ or less of the theoretical value could therefore be taken as evidence for the presence of a restrictive lung disease. This was the case for 11 patients $(52 \%)$ at the time of admission; the values became normal in both the second and third tests.

An obstructive pattern $\left(\mathrm{FEV}_{1} / \mathrm{FVC}<90 \%\right.$ of the predicted value ${ }^{28}$ ) was present initially in 11 patients $(52 \%)$, whereas in four others the value was greater than $110 \%$ of predicted value (fig 2). Little change was noted in the second series of tests. In the convalescent stage, five subjects, four of whom were smokers, had abnormally low values for the $\mathrm{FEV}_{1} / \mathrm{FVC}$ ratio.

The slope of the alveolar plateau (phase 3) of ? the single breath $\mathrm{O}_{2}$ test was abnormal in 12 out of $19(63 \%)$ of our subjects at the time of ado mission. However, in the second series of test $\theta$ only three out of $18(17 \%)$ were abnormal and only one out of $16(6 \%)$ in the third series of tests. Measurements of closing volume were abnormal in only two subjects at the time of admission and in none of the patients at the time of the last examination.

The $\mathrm{AaDO}_{2}$ was abnormal $(>2.6 \mathrm{kPa}$ of $20 \mathrm{~mm} \mathrm{Hg}$ ) in 15 out of 20 patients in the first series of tests, in four out of 17 in the second, and in none out of 16 in the third (fig 3).

Two measurements, MMEF and $V_{75}$ (maxima airflow after $75 \%$ of FVC), were calculated only in the third series of tests since in view oB. the normalisation, at this stage, of the otheis

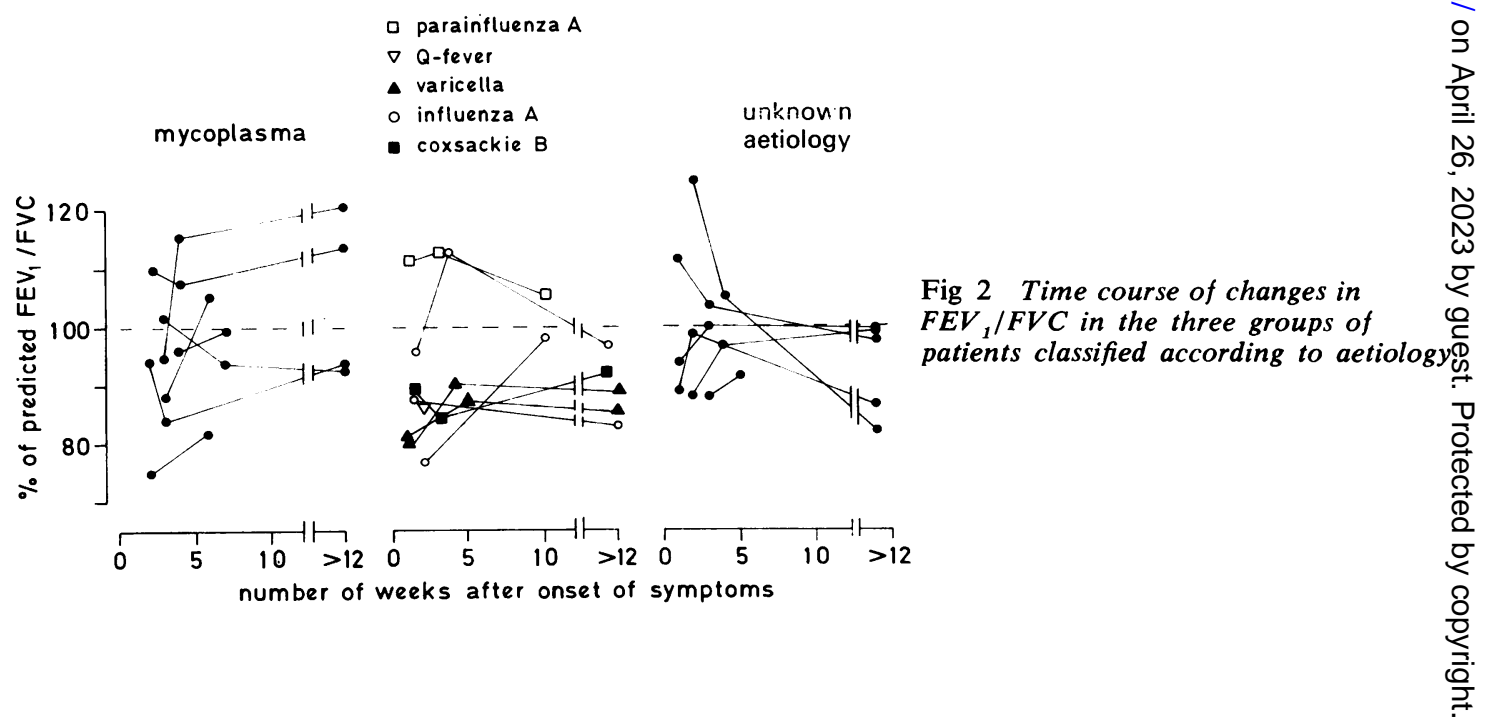




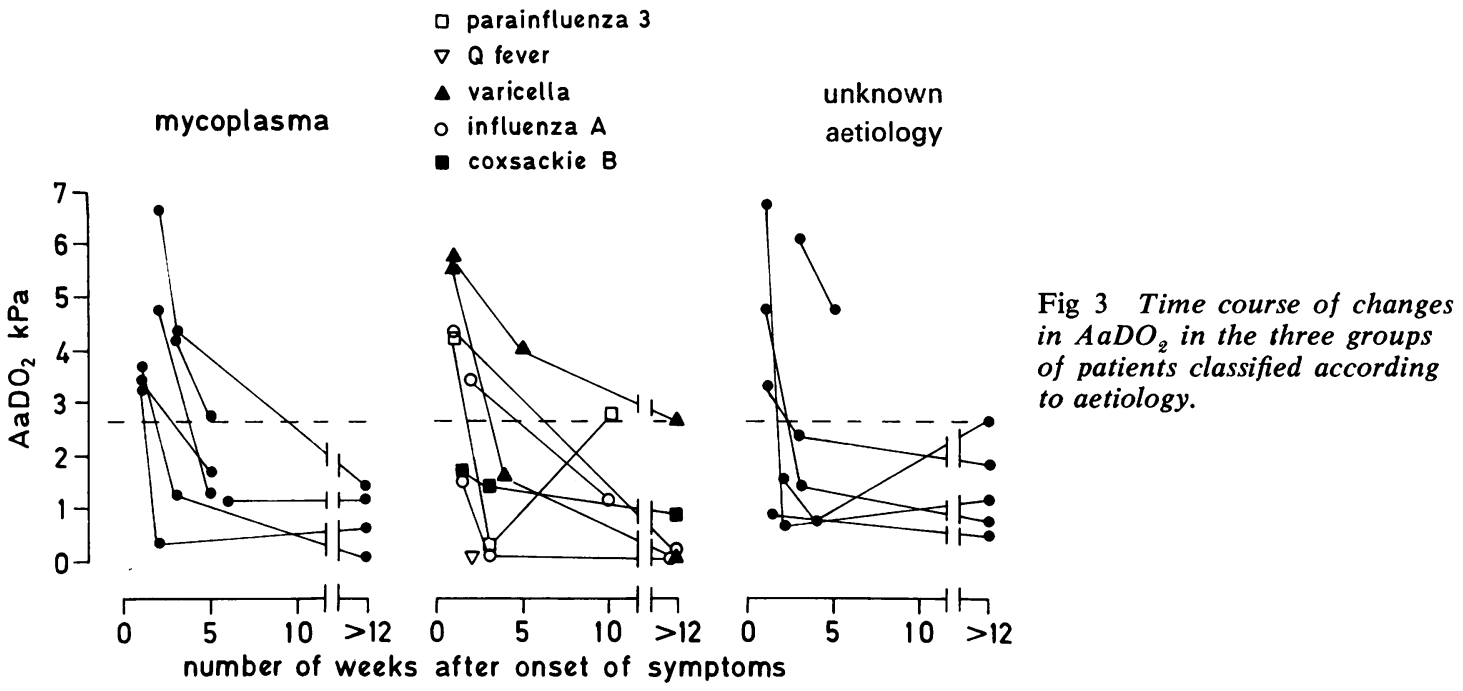

conventional tests, we could use them to assess the presence of "small airways disease." The results are given in table 2, together with the values obtained for $\mathrm{VC}, \mathrm{FEV}_{1} / \mathrm{FVC}$ ratio, and specific conductance. Although few of the measurements of $\dot{\mathrm{V}}_{75}$ and MMEF could be considered as significantly abnormal because of the wide range of normal values, the average value of $\dot{\mathrm{V}}_{75}$, expressed as a percentage of predicted, was only $60 \pm 29 \%$ and that MMEF $80 \pm 27 \%$ (mean \pm SD). Patients having recovered from Mycoplasma pneumonia, however, had normal values for both $\dot{V}_{75}(89 \pm 12 \%)$ and MMEF
$(109 \pm 18 \%)$. If we exclude this group, the average values for the two other groups then became $49 \pm 24 \%$ for $\dot{V}_{75}$ and $66 \pm 22 \%$ for MMEF, making both of them significantly different from the values of the Mycoplasma pneumoniae group $(\mathrm{p}<0.01)$.

\section{Discussion}

There are two factors limiting the conclusions that can be drawn from this study. First, we studied a selected group which excluded patients with acute respiratory distress syndrome and sub-

Table 2 Lung functions in the third series of tests

\begin{tabular}{|c|c|c|c|c|c|c|c|c|}
\hline Aetiology & $\begin{array}{l}\text { Patient } \\
\text { number }\end{array}$ & $\begin{array}{l}\text { Time after } \\
\text { onset of } \\
\text { symptoms } \\
\text { (weeks) }\end{array}$ & $\begin{array}{l}V C \\
(l)\end{array}$ & $\begin{array}{l}F E V_{1} / F V C \\
(\%)\end{array}$ & $\begin{array}{l}\text { Slope } \\
\text { phase III } \\
\left(\% \mathrm{~N}_{2} / l\right)\end{array}$ & $\begin{array}{l}s G a w \\
\left(s^{-1} \cdot k P a^{-1}\right)\end{array}$ & $\begin{array}{l}\dot{V}_{75}(\bar{M} \pm S D)^{*} \\
(l / s / F V C)\end{array}$ & $\begin{array}{l}\underset{(l / s)}{M M E F}(\bar{M} \pm S D)^{*} \\
\text { * }\end{array}$ \\
\hline $\begin{array}{c}\text { Mycoplasma } \\
\text { pneumoniae }\end{array}$ & $\begin{array}{l}3 \\
4 \\
5 \\
7\end{array}$ & $\begin{array}{l}18 \\
68 \\
14 \\
67\end{array}$ & $\begin{array}{l}5 \cdot 50 \\
3 \cdot 85 \\
4 \cdot 80 \\
3 \cdot 45\end{array}$ & $\begin{array}{l}80 \\
78 \\
88 \\
95\end{array}$ & $\begin{array}{l}1 \cdot 0 \\
1 \cdot 0 \\
1 \cdot 0 \\
2 \cdot 0\end{array}$ & $\begin{array}{l}1 \cdot 8 \\
1 \cdot 9 \\
1 \cdot 5 \\
1 \cdot 3\end{array}$ & $\begin{array}{l}0.43(0.60 \pm 0.17) \\
0.63(0.70 \pm 0.29) \\
0.70(0.71 \pm 0.28) \\
0.67(0.70 \pm 0.29)\end{array}$ & $\begin{array}{l}4 \cdot 65(4 \cdot 7 \pm 1 \cdot 12) \\
3 \cdot 01(3 \cdot 3 \pm 0 \cdot 80) \\
5 \cdot 20(4 \cdot 0 \pm 1 \cdot 12) \\
4 \cdot 25(3 \cdot 65 \pm 0 \cdot 80)\end{array}$ \\
\hline Influenza A & $\begin{array}{r}8 \\
9 \\
10\end{array}$ & $\begin{array}{l}16 \\
16 \\
11\end{array}$ & $\begin{array}{l}4 \cdot 05 \\
3 \cdot 70 \\
3 \cdot 20\end{array}$ & $\begin{array}{l}61 \\
82 \\
76\end{array}$ & $\begin{array}{l}2 \cdot 0 \\
2 \cdot 0 \\
2 \cdot 5\end{array}$ & $\begin{array}{l}1 \cdot 4 \\
1 \cdot 2 \\
1 \cdot 5\end{array}$ & $\begin{array}{l}0.13(0.71 \pm 0.28) \\
0.50(0.79 \pm 0.27) \\
0.21(0.75 \pm 0.30)\end{array}$ & $\begin{array}{l}3 \cdot 27(3 \cdot 72 \pm 0 \cdot 80) \\
1 \cdot 87(2 \cdot 79 \pm 0 \cdot 80)\end{array}$ \\
\hline Varicella & $\begin{array}{l}11 \\
12\end{array}$ & $\begin{array}{l}75 \\
67\end{array}$ & $\begin{array}{l}3 \cdot 75 \\
3 \cdot 60\end{array}$ & $\begin{array}{l}72 \\
75\end{array}$ & $\begin{array}{l}2 \cdot 0 \\
1 \cdot 5\end{array}$ & $\begin{array}{l}1 \cdot 7 \\
1 \cdot 6\end{array}$ & $\begin{array}{l}0.27(0.70 \pm 0.29) \\
0.27(0.70 \pm 0.29)\end{array}$ & $\begin{array}{l}1.70(3.62 \pm 0.80) \\
2.42(3.62 \pm 0.80)\end{array}$ \\
\hline Coxsackie B & 13 & 16 & $4 \cdot 20$ & 77 & $1 \cdot 0$ & $1 \cdot 5$ & $0.35(0.70 \pm 0.29)$ & $3 \cdot 21(3 \cdot 34 \pm 0 \cdot 80)$ \\
\hline Parainfluenza A & 15 & 9 & $5 \cdot 90$ & 82 & 0.5 & $1 \cdot 4$ & $0.37(0.59 \pm 0.23)$ & $4 \cdot 60(4 \cdot 51 \pm 1 \cdot 12)$ \\
\hline Unknown & $\begin{array}{l}17 \\
18 \\
19 \\
20 \\
21\end{array}$ & $\begin{array}{l}18 \\
16 \\
14 \\
14 \\
19\end{array}$ & $\begin{array}{l}5 \cdot 21 \\
5 \cdot 60 \\
5 \cdot 40 \\
3 \cdot 45 \\
2 \cdot 35\end{array}$ & $\begin{array}{l}73 \\
80 \\
79 \\
75 \\
63\end{array}$ & $\begin{array}{l}1 \cdot 0 \\
1 \cdot 0 \\
0 \cdot 75 \\
1 \cdot 5 \\
2 \cdot 5\end{array}$ & $\begin{array}{l}1 \cdot 6 \\
1 \cdot 5 \\
2 \cdot 2 \\
1 \cdot 2\end{array}$ & $\begin{array}{l}0.39(0.59 \pm 0.23) \\
0.38(0.59 \pm 0.23) \\
0.76(0.79 \pm 0.27) \\
0.10(0.75 \pm 0.30)\end{array}$ & $\begin{array}{l}2.50(3.97 \pm 1 \cdot 12) \\
2.50(4.17 \pm 1 \cdot 12) \\
3.40(4.42 \pm 1 \cdot 12) \\
2.54(3.75 \pm 0.80) \\
0.62(2.58 \pm 0.80)\end{array}$ \\
\hline
\end{tabular}

* Predicted values ( \pm 1 SD) for $\dot{\mathrm{V}}_{75} / \mathrm{FVC}$ were taken from Knudson et al 26 and those for MMEF from Morris et al. ${ }^{29}$ 
jects with mild illness for whom admission to hospital was not necessary. The second limitation is the small number of cases resulting from each aetiological agent, especially in the mixed group because of its variety of causal agents.

The most obvious conclusion is the variety in the patterns of functional impairment, with evidence in the acute phase of the disease of restriation, obstruction, and abnormalities in the distribution of ventilation and gas exchange in approximately half to two-thirds of the cases. It seems logical, therefore, to infer that several pathophysiological patterns were associated. At this stage, neither smoking nor a particular aetiological agent could be related to a given type of functional abnormality.

Improvement in function was rapid in most cases. The second series of tests, performed two to four weeks after the first series, showed a much reduced prevalence of abnormalities. This was particularly true for the restrictive pattern, the $\mathrm{AaDO}_{2}$ gradient, and the distribution of ventilation, whereas the frequency of obstruction remained at the same level. This discrepancy might result from the fact that the obstructive patten was somewhat underestimated in the first series of tests, the coexistence of a restrictive syndrome having prevented its expression in some patients. Airways obstruction, defined conventionally by reduced $\mathrm{FEV}_{1} / \mathrm{FVC}$ ratio, was the most common disturbance two months or more after the acute episode, but four of the five subjects with this abnormality were smokers. These patients, however, did not show abnormalities in the slope of phase 3 of the single breath $\mathrm{O}_{2}$ manoeuvre.

MMEF and $\dot{V}_{7,}$ were not analysed in the first two series of tests as the data could not be properly interpreted in view of the coexistence of obstructive or restrictive patterns or both in most subjects. However, at a time when most of the conventional lung function tests returned to normal (two to 18 months after the onset of disease), the analysis of flow-volume curves and the measurement of MMEF suggested abnormalities for the group as a whole. Closer examination of the data, however, indicated that the group of patients with Mycoplasma pneumoniae differed from the two other groups by not showing reduced values for $\dot{V}_{7 j}$ and MMEF. Abnormalities in these tests are generally taken as evidence of small airways disease, and we would like to postulate that, late in the recovery period from atypical pneumonia of various aetiologies, but with the exclusion of Mycoplasma pneumoniae, peripheral airways could be involved as was shown to be the case in the acute phase of uncomplicated viral infec-둥 tions. ${ }^{1-5}$ The different behaviour of the group $\overline{\overline{0}}$ with Mycoplasma pneumoniae, which does not? appear to result from a prolonged duration of $\mathscr{Q}$ observation, but might be caused by the different pathophysiology of mycoplasmal and viral $\overrightarrow{0}$ pneumonia as proposed by Brunner et al, ${ }^{30}$ is the only finding which separated one aetiological $\vec{\omega}$ agent from the group as a whole. It is true that strict criteria for pathological (outside $2 \mathrm{SD}) \overrightarrow{\vec{x}}$ reduction in $\dot{V}_{75}$ or MMEF were met only in a w few cases, but, as often reported in studies onio small airways involvement under various con- $-\infty$ ditions, patients who could not be considered as abnormal on an individual basis, could, as a을 group, be differentiated clearly from the group of control subjects. By analogy, the mixed and the unknown aetiology groups could be considere传 as abnormal when compared to the Mycoplasma pneumoniae group, which, because of its ap $\overrightarrow{0}$ parent complete recovery, could be taken as ao control.

Out of five patients with the best evidence for small airways involvement (patients $8,10,11,12$, 21) at the third series of test, three were smokers. Four presented initially an obstructive pattern, $\stackrel{\circ}{\mathbb{Q}}$ with a mean $\mathrm{FEV}_{1} / \mathrm{FVC}$ ratio equal to $87 \%$ of predicted value and a sGaw of $1.7 \mathrm{~s}^{-1} \cdot \mathrm{kPa}^{-1}$ $\left(0.17 \mathrm{~s}^{-1} . \mathrm{cm} \mathrm{H} \mathrm{H}_{2} \mathrm{O}^{-1}\right)$. Out of the 11 other patients, seven were smokers and nine also presented initially an obstructive pattern, with the same$\mathrm{FEV}_{1} / \mathrm{FVC}$ ratio ( $87 \%$ of the predicted value) and a sGaw of $1.4 \mathrm{~s}^{-1} \cdot \mathrm{kPa}^{-1}$. It appears therefore impossible to predict the occurrence of smalk airways involvement from the initial measure-3. ments of $\mathrm{FEV}_{1} / \mathrm{FVC}$ ratio and sGaw. Smoking does not seem to predispose to such functional impairment.

Comparison of our data with those obtained? previously by other investigators reveals someo discrepancies. Thus Stonehill et al ${ }^{14}$ found only a slight reduction in VC $(89 \%$ of the predicted values) in the acute phase of viral respiratory disease with pulmonary infiltrates. Bocles et al ${ }^{15}$ studied 10 subjects with varicella pneumonia in ${ }_{\sigma}^{\omega}$ the acute phase and could not detect any change in VC or $\mathrm{FEV}_{1} / \mathrm{FVC}$ ratio. Berven ${ }^{13}$ found the $\mathrm{AaDO}_{2}$ abnormal in five out of nine patients, $13 \mathbb{C}_{7}$ to 27 weeks after the onset of atypical pneumonia, whereas none of our 16 patients had ano $\mathrm{AaDO}_{2}$ higher than $2.6 \mathrm{kPa}$ in our third series of measurements. Differences in smoking habits, $\frac{\text { के }}{\circ}$ case selection, time of observation, and severity of disease, could explain these discrepancies at least partially. Because of this variability ofo , 
results, some caution is advisable, and our finding of small airways involvement in the late recovery period from all types of atypical pneumonia but Mycoplasma pneumoniae deserves confirmation.

We thank Ms Olivet, Ms Lauper, Ms Gouneaud, and Ms van Muyden for their technical assistance. This work was supported by the Swiss National Science Foundation Grant Number $837 \cdot 457 \cdot 76$.

\section{References}

1 Picken JJ, Niewoehner DE, Chester EH. Prolonged effects of viral infection of the upper respiratory tract on small airways. $A m \mathrm{~J} \mathrm{Med}$ 1972; 52:738-46.

2 Rosenzweig DY, Dwyer DJ, Ferstenfeld JE, Rytel MW. Changes in small airway function after live attenuated influenza vaccination. $A m$ Rev Respir Dis 1975; 111:399-403.

3 Blair HT, Greenberg SB, Stevens PM, Bilunos PA, Couch RB. Effects of rhinovirus infection on pulmonary function of healthy human volunteers. Am Rev Respir Dis 1976; 114:95-102.

4 Hall WJ, Douglas RG, Hyde RW, Roth FK, Cross AS, Speers DM. Pulmonary mechanics after uncomplicated influenza $\mathrm{A}$ infection. $\mathrm{Am}$ Rev Respir Dis 1976; 113:141-7.

5 Hobbins TE, Chen CS, Holley HP Jr et al. Respiratory function changes following live, attenuated, temperature-sensitive (ts) influenza vaccine. Am Rev Respir Dis 1977; 115:263.

6 Johanson WG Jr, Pierce AK, Sanford JP. Pulmonary function in uncomplicated influenza. Am Rev Respir Dis 1969; 100:141-6.

7 Cate TR, Roberts JS, Russ MA, Pierce JA. Effects of common colds on pulmonary function. Am Rev Respir Dis 1973; 108:858-69.

8 Horner GJ, Gray FD Jr. Effect of uncomplicated, presumptive influenza on the diffusing capacity of the lung. Am Rev Respir Dis 1973; 189:866-9.

9 Little JW, Hall WJ, Douglas RG, Hyde RW, Speers DM. Amantadine effect on peripheral airways abnormalities in influenza. A study in 15 students with natural influenza A infection. Ann Intern Med 1976; 85:177-82.

10 Fridy WW Jr, Ingram RH, Hierholzer JC, Coleman MT. Airways function during mild viral respiratory illnesses. The effect of rhinovirus infection in cigarette smokers. Ann Intern Med 1974; 80:150-5.

11 Zeck R, Solliday $\mathrm{N}$, Kehoe $\mathbf{T}$, Berlin $\mathrm{B}$. Respiratory effects of live influenza virus vaccine: healthy older subjects and patients with chronic respiratory disease. Am Rev Respir Dis 1976; 114:1061-7.

12 Hall WJ, Hall CB, Speers DM. Clinical and physiologic characteristics of respiratory syncytial virus (RSV) infection in adults. Am Rev Respir
Dis 1977; 115:115.

13 Berven $H$. Studies on the cardiopulmonary function in the post-infectious phase of "atypical" pneumonia. Acta Med Scand 1962; suppl 382.

14 Stonehill RB, Schalet N, Fong WY, Saltzman H, Houser HB. Pulmonary ventilatory function in military recruits during health and acute viral respiratory disease, including pneumonia. $\mathrm{Am}$ Rev Respir Dis 1960; 81:315-20.

15 Bocles JS, Ehrenkranz NJ, Marks A. Abnormalities of respiratory function in varicella pneumonia. Ann Intern Med 1964; 60:183-195.

16 Kennedy MCS, Miller DL, Pearson AJ. Respiratory function of recruits to the Royal Air Force in health and during acute respiratory diseases. Br J Dis Chest 1965; 59:10-14.

17 Klocke RA, Artenstein MS, Green RW, Dennehy JJ, Richert JH. The effect of acute respiratory infection on pulmonary function in military recruits. Am Rev Respir Dis 1966; 93:549-55.

18 Finucane, KE, Colebatch HJH, Robertson MR, Gandevia $\mathrm{BH}$. The mechanism of respiratory failure in a patient with viral (varicella) pneumonia. Am Rev Respir Dis 1970; 101:949-58.

19 Winterbauer RH, Ludwig WR, Hammar SP. Clinical course, management, and long-term sequelae of respiratory failure due to influenza viral pneumonia. Johns Hopkins Med J 1977; 141:148-55.

20 Hall CB, Douglas RG Jr. Clinically useful method for the isolation of respiratory syncytial virus. J Infect Dis 1975; 131:1-5.

21 Hsiung GD. Diagnostic virology. New Haven: Yale University Press, 1973.

22 US Department of Health, Education and Welfare. A guide to the performance of the standardized diagnostic complement fixation method and adaption to the micro test. Washington: US DHEW, 1969.

23 Du Bois AB, Botelho SY, Bedell GN, Marshall R, Comroe JH Jr. A rapid plethysmographic method for measuring thoracic gas volume: a comparison with a nitrogen washout method for measuring functional residual capacity in normal subjects. J Clin Invest 1956; 35:322-6.

24 Du Bois AB, Botelho SY, Comroe JH Jr. A new method for measuring airway resistance in man using a body plethysmograph: values in normal subiects and in patients with respiratory disease. $J$ Clin Invest 1956; 35:327-35.

25 Buist AS, Ross BB. Quantitative analysis of the alveolar plateau in the diagnosis of early airway obstruction. Am Rev Respir Dis 1973; 108: 1078-87.

26 Knudson RJ, Slatin RC, Lebowitz MD, Burrows B. The maximal expiratory flow-volume curve. Normal standards, variability and effects of age. Am Rev Respir Dis 1976: 113:587-600.

27 Goldman HI, Becklake WR. Respiratory function tests: normal values at median altitudes and the prediction of normal results. $A m \quad R e v$ Tuberculosis 1959; 79:457-67. 
28 Berglund E, Birath G, Bjure J et al. Spirometric studies in normal subjects. Acta Med Scand 1963; 173:185-206.

29 Morris JF, Koski A, Breese JD. Normal values and evaluation of forced end-expiratory flow. Am Rev Respir Dis 1975; 111:755-62.
30 Brunner H, Prescott B, Greenberg H, James WD Horswood RL, Chanock RM. Unexpectedly high? frequency of antibody to Mycoplasma pneumoniae in human sera as measured by sensitive techniques. J Infect Dis 1977; 135 524-30.

The provisional programme includes the following subjects. The patient: pathophysiological response to extra-corporeal circulation. Materials: bioengineering and biocompatibility of plastics. Prospects for the bionic man: prosthetics, and the current state of the art. Organ support: lungs, heart, kidney, and liver. Current practice: oxygenators, pumps, techniques. Further details may be obtained from the Congress Organiser, Conference Clearway, Conference House, 9 Pavilion Parade, Brighton BN2 1RA. 